Запропоновано модель гомогенізащіі трансверсальноізотропного композитного матеріалу, механічні характеристики якого при поздовжньому розтягу та стиску відрізняються між собою. На ї̈ основі отримано поздовжній модуль пружності першого роду та коефічієнт Пуассона для різномодульного композиту. Ці показники необхідні для проектування елементів конструкцій, що виготовляються з композитів. Об'єктом дослідження є односпрямований волокнистий композит, що складається з ізотропних пружних матрииі та волокна. Для визначення ефективних пружних сталих пропонуеться підхід, що грунтуеться на використанні умов узгодження переміщень точок гомогенізованого композиту, матриці та волокна.

Спочатку визначаються перемімення та напруження для точок матриці та волокна при їх сумісному осесиметричному розтягу. Для розв'язання иієї задачі попередньо отримано рівняння різномодульної теорії пружності. Аналогічні компоненти напружено-деформованого стану визначаються при такому ж деформуванні ииліндричної комірки з однорідного трансверсально-ізотропного композиту. Умовами узгодженості переміщень, отриманих при розв'язанні вказаних задач, є рівність осьових переміщень у довільному перерізі композиту площиною, паралельною площині ізотропї̈, та радіальних переміщень на поверхні комірки композиту. У результаті використання иих умов отримано формули для ефективних констант - поздовжнього модуля пружності першого роду та коефічієнта Пуассона, що виражають иі показники через механічні характеристики матрищі та волокна, а також иастку волокна у об'ємі комірки композита. Аналогічні формули отримано для поздовжньго стиску.

Отримані ефективні пружні характеристики трансверсально-ізотропного композиту можуть бути використані при розрахунку напружено-деформованого стану виготовлених 3 нього елементів конструкцій. При иьому враховуються відмінності у значеннях напружень та деформацій при осьових розтягу та стиску

Ключові слова: гомогенізачія, різномодульний трансверсально-ізотропний композит, напруження, переміщення, деформачї, ефективні сталі
UDC 539.3
DOI: $10.15587 / 1729-4061.2020 .199968$

\section{THE HOMOGENIZATION OF MULTI-MODULAR COMPOSITES AT THEIR LONGITUDINAL DEFORMATION}

\author{
S. G re be n y u k \\ Doctor of Technical Sciences, Associate \\ Professor, Head of Department* \\ E-mail: gsm1212@ukr.net \\ T. S moliankova \\ Postgraduate Student* \\ E-mail: t.smolyankova@ukr.net \\ M. K I y men ko \\ $\mathrm{PhD}$, Associate Professor* \\ E-mail: m1655291@gmail.com \\ O. Kudin \\ $\mathrm{PhD}$, Associate Professor** \\ E-mail: avk256@gmail.com \\ *Department of Fundamental Mathematics $* * *$ \\ **Department of Software Engineering*** \\ $\star * *$ Zaporizhzhia National University \\ Zhukovskoho str., 66, Zaporizhzhia,
} Ukraine, 69600
Received date 30.10.2019

Accepted date 27.03.2020

Published date 19.06.2020
Copyright (C) 2020, S. Grebenyuk, T. Smoliankova, M. Klymenko, O. Kudin This is an open access article under the CC BY license (http://creativecommons.org/licenses/by/4.0)

\section{Introduction}

Requirements of technological progress give rise to the need to create new structural materials, among which an important place belongs to composites. The application of composite materials makes it possible to optimize the technical and operational properties of the structures made from them.

It is impossible to calculate the stressed-strained state of a fibrous composite as a fiber system reinforced by a matrix because of the huge number of such inclusions. In this regard, there is a need for the homogenization of a composite material. The effective physical and mechanical characteristics, obtained in this case, are used in the design and calculation of structures made from composites.

Modern technology widely employs those composites whose physical-mechanical characteristics differ at stretching and compression. Such materials are called multimodular (bimodular) because their elastic constants that relate the stresses and deformations accept different values at stretching and compression. A multimodular material shows different elastic properties in different directions depending on the signs of the principal stresses. At present, the effective characteristics of multimodular composites are determined by the statistical treatment of experimental data. This path implies significant costs. Given this, it appears a relevant task to construct mathematical models for defining the effective characteristics of multimodular composites. The application of mathematical modeling avoids additional costs for experiments. The knowledge of the effective elastic constants for multi-modular composites would solve the task of determining the components of their stressed-strained state, which could create possibilities for successfully applying these materials in practice. Therefore, it is a relevant task to undertake a study aimed at deriving their effective mechanical characteristics.

\section{Literature review and problem statement}

Papers [1-7] resolved the task of homogenizing the fibrous composites, without considering their multimodularity, for a matrix and different types of fibers. The authors examined the composite materials with anisotropic, plastic, viscoelastic components. In particular, study [1] suggested 
formulae for the elastic characteristics of a fibrous composite with the isotropic matrix and transversally-isotropic fiber; the differences in these characteristics at stretching and compression were not taken into consideration. The homogenization of the viscoelastic composites was considered in [2-6]. In [2], an asymptomatic approach was used to homogenize the composites, excluding a multimodularity phenomenon. A similar simplification was applied in [3] when homogenizing the composites; a Kelvin-Voigt model was used to describe their viscoelastic properties. In [4], numerical simulation of the viscoelastic properties of the anisotropic composites was also carried out under the simplifying assumption about their mechanical characteristics' constancy at the stretching and compression deformation. In study [5], an effective longitudinal elasticity module for a viscoelastic transversally-isotropic composite was determined on the basis of the harmonization of displacements of the homogenized composite and its components. These displacements were determined by disregarding the phenomenon of multimodularity. Publication [6] gives an overview of the analytical micromechanical models of elastic-plastic composites; however, there are no models, which take into consideration the differences between the mechanical characteristics of composites at the stretching and compression deformation. Study [7] reports a model of the asymptomatic homogenization of a composite, taking into consideration plastic deformations of its components based on a variational approach. The phenomenon of multimodularity was not taken into consideration in the cited study.

The fundamentals of the classic multimodular elasticity theory are outlined in monograph [8]. It gives the main assumptions and equations for the stressed-strained state of homogeneous materials with mechanical characteristics that differ at stretching and compression, as well as the basic ratios related to the multimodular theory of elasticity, applied in the current paper. Work [9] derived the equations related to the multimodular theory of elasticity, based on the assumption about a constant shear module and the dependence of the volumetric module of elasticity on the first invariant of a stress tensor. However, there is no study into the possibilities of using these equations to solve a problem on the homogenization of fibrous composites. The cited publications considered a homogeneous multi-modular material. Papers $[10,11]$ prove, on the basis of experimental data, the presence of the properties of multimodularity in different types of grain composites; however, no mathematical models that would take into consideration this property were constructed. A mathematical model of an isometric multimodular body, considered to be homogeneous, was proposed in [12]. Its application for studying composite materials was not considered there. Article [13] explores the mechanical properties of multimodular reinforced concrete but does not offer any mathematical models for its homogenization. The review of the above studies shows that at present there are almost no studies, which determine the effective mechanical characteristics of fibrous composites taking into consideration the properties of different modularity. A mathematical model of the homogenization of a multimodular transversally-isotropic fibrous composite at transverse deformation is proposed in [14]. Based on it, the authors determined the effective transverse module of elasticity for a multimodular composite at stretching and compression. The multimodularity of materials is taken into consideration by using appropriate models of the isotropic and transversally-isotropic materials. The equations that ultimately determine them were built in analogy to the basic ratios related to the multimodular theory of elasticity. Paper [14] determined only one of the five elastic constants that determine the mechanical properties of a composite at the stretching and compression deformations.

Our analysis of studies into the homogenization of composites reveals that there has been an unresolved issue of determining all the effective constants that characterize the multimodular mechanical properties of the transversallyisotropic composite. In particular, there are no formulae for defining an effective longitudinal module of elasticity, shear module, and Poisson coefficients, for the stretching and compression of a fibrous composite with the transversally-isotropic properties.

\section{The aim and objectives of the study}

The aim of this study is to determine the effective elastic constants - a longitudinal module of elasticity of the first kind and a Poisson's coefficient for a multimodular transversally-isotropic fibrous composite. This would make it possible to apply them in addressing the practical problems on the statics and dynamics of parts and structures made from different composite materials.

To accomplish the aim, the following tasks have been set:

- to devise a homogenization procedure of a transversally-isotropic composite, which takes into consideration the differences in its mechanical properties at the longitudinal stretching and compression, and is based on the use of the kinematic conditions for the alignment of displacements points of the composite and its constituent elements;

- to solve auxiliary problems on determining the displacements of the matrix and fibers at their joint longitudinal stretching and compression, as well as determining the displacements of points in a homogeneous transversally-isotropic composite under its longitudinal deformation;

- to derive formulae for the effective values of the longitudinal module of elasticity of the first kind and Poisson's coefficient in the isotropy plane of a fibrous composite at stretching and compression;

- to apply the formulae derived for the homogenization of a multimodular composite.

\section{Procedure for the homogenization of a multimodular transversally-isotropic composite at the longitudinal stretching and compression}

We suggest a procedure for determining the effective elastic constants for a transversally-isotropic multi-modular fibrous composite at stretching and compression, which is based on the application of the kinematic conditions for aligning the displacements of the composite and its components. Its essence is as follows.

At the first stage, we solve an auxiliary problem on the deformation of the matrix and fibers at longitudinal stretching and compression of the representative composite cell and find their axial and radial displacements.

At the second stage, an auxiliary problem is solved on finding the axial and radial displacements of points in a homogeneous composite at its longitudinal stretching and compression. 
In the third phase, the values of the effective elastic constants, an elasticity longitudinal module, and a Poisson coefficient, are determined for each type of the deformation. The longitudinal module of elasticity is found by equating the axial displacements of points in the homogeneous composite and matrix (the latter coincide with the axial displacements of fiber points), derived from solving the auxiliary problems. We consider the cases of stretching and compression separately. The effective values of a Poisson coefficient for stretching and compression are determined from the condition for equality of the corresponding radial displacements on the surface of the composite cell, found from solving the first and second auxiliary problems.

A modification of a given procedure, without taking into consideration the phenomenon of multimodularity, was used to homogenize the viscoelastic composites in [5].

Let the cell of a fibrous unidirectional composite consist of the isotropic elastic multimodular matrix and fiber. The cell consists of a solid cylinder that simulates a fiber and a hollow matrix cylinder.

The elasticity modulus and Poisson's ratio at stretching are denoted via $E_{+}$and $v_{+}$at compression, $E_{-}$and $v_{-}$, respectively. The material of the fiber is exposed to the evenly distributed stress $\sigma_{+}^{\circ}>0$ in the direction of the $z$-axis. This axis coincides with the cylinder axis, which approximates the composite cell. Similar stress, $\sigma_{+}^{*}>0$, acting in the material of the matrix is selected such that the axial displacements of the matrix and fibers match for an arbitrary cross-section $z=h=$ const.

Hereafter, we apply the basic prerequisites and assumptions from the multimodular theory of elasticity, as well as its main equations, outlined and substantiated in monograph [8]. In particular, it is assumed that under a longitudinal axisymmetric deformation (stretching or compression) in the axial direction the normal stresses in the cylindrical coordinate system of the composite cell are the principal stresses (tangent stresses are zero). In this case, the coordinate axes of the cylindrical coordinate system are the main axes. At stretching, the radial and tangential strains are negative and the axial stress is positive. At compression, signs of the principal stresses change to the opposite. Thus, Hooke's law for the isotropic components of a composite is used in the form similar to [8].

For the longitudinal stretching of the composite cell in the direction of the $z$ coordinate, the formulae from the Hooke's law in a direct form for an isotropic body take the following form:

$$
\begin{aligned}
& \varepsilon_{r}=\frac{1}{E_{-}}\left(\sigma_{r}-v_{-}\left(\sigma_{\theta}+\sigma_{z}\right)\right), \\
& \varepsilon_{\theta}=\frac{1}{E_{-}}\left(\sigma_{\theta}-v_{-}\left(\sigma_{r}+\sigma_{z}\right)\right), \\
& \varepsilon_{z}=\frac{1}{E_{+}}\left(\sigma_{z}-v_{+}\left(\sigma_{r}+\sigma_{\theta}\right)\right) .
\end{aligned}
$$

By expressing strains through deformations, we obtain the formulae abiding the Hooke's law in the inverse form:

$$
\sigma_{r}=\frac{1}{\Delta}\left(\begin{array}{l}
E_{-}\left(1-v_{-} v_{+}\right) \varepsilon_{r}+E_{-} v_{-}\left(1+v_{+}\right) \varepsilon_{\theta}+ \\
+E_{+} v_{-}\left(1+v_{-}\right) \varepsilon_{z}
\end{array}\right)
$$

$$
\begin{aligned}
& \sigma_{\theta}=\frac{1}{\Delta}\left(\begin{array}{l}
E_{-} v_{-}\left(1+v_{+}\right) \varepsilon_{r}+E_{-}\left(1-v_{+} v_{-}\right) \varepsilon_{\theta}+ \\
+E_{+} v_{-}\left(1+v_{-}\right) \varepsilon_{z}
\end{array}\right), \\
& \sigma_{z}=\frac{1}{\Delta}\left(\begin{array}{l}
E_{-} v_{+}\left(1+v_{-}\right) \varepsilon_{r}+E_{-} v_{+}\left(1+v_{-}\right) \varepsilon_{\theta}+ \\
+E_{+}\left(1-\left(v_{-}\right)^{2}\right) \varepsilon_{z}
\end{array}\right) .
\end{aligned}
$$

In formulae (4) to (6), $\Delta=\left(1+v_{-}\right)\left(1-v_{-}-2 v_{+} v_{-}\right), \sigma_{r}, \sigma_{\theta}$, $\sigma_{z}$ are the normal displacements in the direction of the $r, \theta, z$ coordinate axes in the cylindrical coordinate system; $\varepsilon_{r}, \varepsilon_{\theta}$, $\varepsilon_{z}$ are the linear deformations in the direction of these axes.

The discrepancies between the classical and multimodular theories of elasticity are found only in the ratios of stresses to deformations; other basic equations from the elasticity theory hold in both cases [8]. Consider the axisymmetric stressed-strained state of a cylindrical body under the action of stretching strain $\sigma$ that operates in the direction of the $z$-axis. Then, at its points $\sigma_{z}=\sigma, \sigma_{r}=\sigma_{r}(r)$, $\sigma_{\theta}=\sigma_{\theta}(r), \tau_{z r}=\tau_{\theta z}=\tau_{r \theta}=0$. The Cauchy formulae take the following form:

$$
\varepsilon_{r}=\frac{\mathrm{d} u_{r}}{\mathrm{~d} r}, \quad \varepsilon_{\theta}=\frac{u_{r}}{r}, \quad \varepsilon_{z}=\frac{\mathrm{d} u_{z}}{\mathrm{~d} z}=\text { const. }
$$

Here $u_{r}$ and $u_{z}$ are, accordingly, the radial and axial displacement. Using the formulae from the Hooke's law in the inverse form, as well as the Cauchy formulae, the equilibrium equation

$$
\frac{\mathrm{d} \sigma_{r}}{\mathrm{~d} r}+\frac{\sigma_{r}-\sigma_{\theta}}{r}=0
$$

shall be recorded in the displacements. It takes the form:

$$
\frac{\mathrm{d}^{2} u_{r}}{\mathrm{~d} r^{2}}+\frac{1}{r} \frac{\mathrm{d} u_{r}}{\mathrm{~d} r}-\frac{u_{r}}{r^{2}}=0 .
$$

Equations (7) to (9) for the classical and multi-modular elasticity theories coincide [8].

The radial displacement $u_{r}(r)$, which is the solution to equation (9), takes the following form:

$$
u_{r}(r)=C_{1} \cdot r+\frac{C_{2}}{r}
$$

where $C_{1}$ and $C_{2}$ are the constants that are determined from the boundary conditions.

\section{Joint deformation of the fiber and matrix at longitudinal stretching}

Consider a joint deformation of the matrix and fiber at longitudinal stretching. The cell is exposed to a stretching force, which creates, at its points, a constant strain $\sigma_{+}^{\circ}>0$ for the fiber and $\sigma_{+}^{*}>0$ for the matrix.

Write down the displacements, deformations, and strains for the matrix and fiber by using the Cauchy formulae and the Hooke's law. For the matrix, we obtain the following equalities:

$$
u_{r}^{*}=B_{1} \cdot r+\frac{B_{2}}{r}, \quad \varepsilon_{r}^{*}=B_{1}-\frac{B_{2}}{r^{2}}, \quad \varepsilon_{\theta}^{*}=B_{1}+\frac{B_{2}}{r^{2}},
$$




$$
\begin{aligned}
& \varepsilon_{z}^{*}=\frac{\sigma_{+}^{*}\left(1-v_{-}^{*}-2 v_{-}^{*} v_{+}^{*}\right)}{E_{+}^{*}\left(1-v_{-}^{*}\right)}-\frac{2 E_{-}^{*} v_{+}^{*} B_{1}}{E_{+}^{*}\left(1-v_{-}^{*}\right)}, \\
& \sigma_{r}^{*}=\frac{E_{-}^{*}}{\left(1-v_{-}^{*}\right)} \cdot B_{1}-\frac{E_{-}^{*}}{\left(1+v_{-}^{*}\right)} \cdot \frac{B_{2}}{r^{2}}+\frac{v_{-}^{*}}{\left(1-v_{-}^{*}\right)} \cdot \sigma_{+}^{*} .
\end{aligned}
$$

The radial displacements and stresses at fiber points, as well as the linear deformations at these points, take the following form:

$$
\begin{aligned}
& u_{r}^{\circ}=A_{1} \cdot r, \\
& \varepsilon_{r}^{\circ}=A_{1}, \varepsilon_{\theta}^{\circ}=A_{1}, \\
& \varepsilon_{z}^{\circ}=\frac{\sigma_{+}^{\circ}\left(1-v_{-}^{\circ}-2 v_{-}^{\circ} v_{+}^{\circ}\right)}{E_{+}^{\circ}\left(1-v_{-}^{\circ}\right)}-\frac{2 E_{-}^{\circ} v_{+}^{\circ} A_{1}}{E_{+}^{\circ}\left(1-v_{-}^{\circ}\right)}, \\
& \sigma_{r}^{\circ}=\frac{E_{-}^{\circ}}{\left(1-v_{-}^{\circ}\right)} \cdot A_{1}+\frac{v_{-}^{\circ}}{\left(1-v_{-}^{\circ}\right)} \cdot \sigma_{+}^{\circ} .
\end{aligned}
$$

If there is a perfect contact at the interface between a matrix and a fiber, the conditions for the continuity of the normal components of displacements and stresses hold. The outer surface of the composite cell is free from stresses. Therefore, the boundary conditions for a problem on the joint matrix and fiber deformation take the following form:

$$
\begin{aligned}
& \sigma_{r}^{*}(a)=\sigma_{r}^{o}(a), u_{r}^{*}(a)=u_{r}^{o}(a), \\
& u_{z}^{*}(h)=u_{z}^{o}(h), \sigma_{r}^{*}(b)=0 .
\end{aligned}
$$

Using conditions (17), we obtain a system to determine the unknown $A_{1}, B_{1}, B_{2}$ and the ratios between $\sigma_{+}^{\circ}$ and $\sigma_{+}^{*}$ :

$$
\left\{\begin{array}{l}
\frac{E_{-}^{*}}{\left(1-v_{-}^{*}\right)} \cdot B_{1}-\frac{E_{-}^{*}}{\left(1+v_{-}^{*}\right)} \cdot \frac{B_{2}}{r^{2}}+\frac{v_{-}^{*}}{\left(1-v_{-}^{*}\right)} \cdot \sigma_{+}^{*}= \\
=\frac{E_{-}^{o}}{\left(1-v_{-}^{o}\right)} \cdot A_{1}+\frac{v_{-}^{o}}{\left(1-v_{-}^{o}\right)} \cdot \sigma_{+}^{o}, \\
B_{1} \cdot a+\frac{B_{2}}{a}=A_{1} \cdot a, \\
\frac{\sigma_{+}^{*}\left(1-v_{-}^{*}-2 v_{-}^{*} v_{+}^{*}\right)}{E_{+}^{*}\left(1-v_{-}^{*}\right)}-\frac{2 E_{-}^{*} v_{+}^{*} B_{1}}{E_{+}^{*}\left(1-v_{-}^{*}\right)}= \\
=\frac{\sigma_{+}^{o}\left(1-v_{-}^{o}-2 v_{-}^{o} v_{+}^{o}\right)}{E_{+}^{o}\left(1-v_{-}^{o}\right)}-\frac{2 E_{-}^{o} v_{+}^{o} A_{1}}{E_{+}^{o}\left(1-v_{-}^{o}\right)}, \\
\frac{E_{-}^{*}}{\left(1-v_{-}^{*}\right)} \cdot B_{1}-\frac{E_{-}^{*}}{\left(1+v_{-}^{*}\right)} \cdot \frac{B_{2}}{b^{2}}+\frac{v_{-}^{*}}{\left(1-v_{-}^{*}\right)} \cdot \sigma_{+}^{*}=0 .
\end{array}\right.
$$

We obtain from the second equation of the system:

$$
A_{1}=B_{1}+\frac{B_{2}}{a^{2}}
$$

We derive from the last equation of the system:

$$
B_{1}=\frac{1-v_{-}^{*}}{1+v_{-}^{*}} \cdot \frac{B_{2}}{b^{2}}-\frac{v_{-}^{*}}{E_{-}^{*}} \cdot \sigma_{+}^{*} \text {. }
$$

\footnotetext{
Considering (20), condition (19) takes the form:
}

$$
A_{1}=B_{2} \cdot\left(\frac{f\left(1-v_{-}^{*}\right)+\left(1+v_{-}^{*}\right)}{a^{2}\left(1+v_{-}^{*}\right)}\right)-\frac{v_{-}^{*}}{E_{-}^{*}} \cdot \sigma_{+}^{*} .
$$

We obtain from the first equality in (17):

$$
\begin{aligned}
& \frac{E_{-}^{o}}{\left(1-v_{-}^{o}\right)} \cdot\left(\frac{v_{-}^{o} \sigma_{+}^{o}}{E_{-}^{o}}-\frac{v_{-}^{*} \sigma_{+}^{*}}{E_{-}^{*}}\right)= \\
& =\frac{B_{2}}{a^{2}} \cdot\left(\frac{E_{-}^{*}(f-1)}{\left(1+v_{-}^{*}\right)}-\frac{E_{-}^{o}\left(f\left(1-v_{-}^{*}\right)+\left(1+v_{-}^{*}\right)\right)}{\left(1-v_{-}^{o}\right)\left(1+v_{-}^{*}\right)}\right) .
\end{aligned}
$$

Suppose $f=\frac{a^{2}}{b^{2}}$ is the relative volumetric part of the fiber in a composite.

We obtain from equality (22):

$$
\begin{aligned}
& B_{2}=\left(\frac{v_{-}^{o} \sigma_{+}^{o}}{E_{-}^{o}}-\frac{v_{-}^{*} \sigma_{+}^{*}}{E_{-}^{*}}\right) \times \\
& \times \frac{a^{2} E_{-}^{o}\left(1+v_{-}^{*}\right)}{E_{-}^{*}(f-1)\left(1-v_{-}^{o}\right)-E_{-}^{o}\left(f\left(1-v_{-}^{*}\right)+\left(1+v_{-}^{*}\right)\right)} .
\end{aligned}
$$

Introduce designations:

$$
\begin{aligned}
& d_{1}=E_{-}^{*}(f-1)\left(1-v_{-}^{o}\right), \\
& d_{2}=E_{-}^{o}\left(f\left(1-v_{-}^{*}\right)+\left(1+v_{-}^{*}\right)\right) .
\end{aligned}
$$

Then

$$
\begin{aligned}
& B_{2}=\frac{v_{-}^{o} a^{2}\left(1+v_{-}^{*}\right)}{d_{1}-d_{2}} \cdot \sigma_{+}^{o}-\frac{a^{2} E_{-}^{o}\left(1+v_{-}^{*}\right)}{d_{1}-d_{2}} \cdot \frac{v_{-}^{*}}{E_{-}^{*}} \cdot \sigma_{+}^{*}, \\
& A_{1}=\frac{d_{2}}{d_{1}-d_{2}} \cdot \frac{v_{-}^{o}}{E_{-}^{o}} \sigma_{+}^{o}-\frac{v_{-}^{*}}{E_{-}^{*}} \cdot \frac{d_{1}}{d_{1}-d_{2}} \cdot \sigma_{+}^{*}, \\
& B_{1}=\frac{f v_{-}^{o}\left(1-v_{-}^{*}\right)}{d_{1}-d_{2}} \cdot \sigma_{+}^{o}-\frac{v_{-}^{*}}{E_{-}^{*}} \cdot \frac{\left(f E_{-}^{o}\left(1-v_{-}^{*}\right)+d_{1}-d_{2}\right)}{d_{1}-d_{2}} \cdot \sigma_{+}^{*} .
\end{aligned}
$$

We obtain, from the third equality in (17), the ratios of $\sigma_{0}^{*}$ to $\sigma_{0}^{\circ}$ :

$$
\begin{aligned}
& \left(\frac{\left(1-2 v_{-}^{\circ} v_{+}^{\circ}-v_{+}^{\circ}\right)\left(d_{1}-d_{2}\right)}{E_{+}^{\circ}\left(1-v_{+}^{\circ}\right)}-\frac{2 v_{-}^{\circ} v_{+}^{\circ} d_{2}}{E_{+}^{\circ}\left(1-v_{+}^{\circ}\right)}+\frac{2 f v_{+}^{\circ} v_{+}^{*}}{1}\right) \sigma_{0}^{\circ}= \\
& =\left(\frac{\left(1-2 v_{-}^{*} v_{+}^{*}-v_{+}^{*}\right)\left(d_{1}-d_{2}\right)}{E_{+}^{*}\left(1-v_{+}^{*}\right)}+\frac{2 v_{-}^{*} v_{+}^{*}\left(f E_{+}^{\circ}\left(1-v_{+}^{*}\right)+d_{1}-d_{2}\right)}{E_{+}^{*}\left(1-v_{+}^{*}\right)}-\right. \\
& \left.-\frac{2 v_{-}^{*} v_{+}^{\circ} d_{1}}{E_{+}^{*}\left(1-v_{+}^{\circ}\right)}\right) \sigma_{0}^{*} .
\end{aligned}
$$

By denoting

$d_{+}^{\circ}=\frac{E_{+}^{*}(f-1)\left(1-v_{+}^{\circ}-2 v_{-}^{\circ} v_{+}^{\circ}\right)-E_{+}^{\circ}\left(f\left(1-v_{+}^{*}-2 v_{-}^{\circ} v_{+}^{*}\right)+\left(1+v_{+}^{*}\right)\right)}{E_{+}^{\circ}}$

$d_{+}^{*}=\frac{E_{+}^{*}(f-1)\left(1-v_{+}^{\circ}-2 v_{-}^{*} v_{+}^{\circ}\right)-E_{+}^{\circ}\left(f\left(1-v_{+}^{*}-2 v_{-}^{*} v_{+}^{*}\right)+\left(1+v_{+}^{*}\right)\right)}{E_{+}^{*}}$ 


$$
d_{+}^{\circ} \sigma_{0}^{\circ}=d_{+}^{*} \sigma_{0}^{*}
$$

Thus, we have obtained the components of the displacements, stresses, and deformations of the matrix and the fiber required for further study.

\section{The longitudinal deformation of a homogeneous} transversally-isotropic composite

Next, solve a similar problem on a homogeneous transversally-isotropic material that simulates the composite. The stress field is determined from the ratios:

$$
\begin{aligned}
& \sigma_{z}=\sigma_{0}, \quad \sigma_{r}=0, \quad \sigma_{\theta}=0, \\
& \tau_{z r}=\tau_{\theta z}=\tau_{r \theta}=0 .
\end{aligned}
$$

To ensure that the equilibrium conditions are matched for both problems, the following condition must be met:

$$
\pi a^{2} \sigma_{0}^{\circ}+\pi\left(b^{2}-a^{2}\right) \sigma_{0}^{*}=\pi b^{2} \sigma_{0}
$$

or

$$
\sigma_{0}^{\circ} f+\sigma_{0}^{*}(1-f)=\sigma_{0} .
$$

We obtain, considering dependence (31):

$$
\sigma_{0}^{*}=\frac{\sigma_{0} d_{+}^{\circ}}{d_{+}^{\circ}+f\left(d_{+}^{*}-d_{+}^{\circ}\right)}, \quad \sigma_{0}^{\circ}=\frac{\sigma_{0} d_{+}^{*}}{d_{+}^{\circ}+f\left(d_{+}^{*}-d_{+}^{\circ}\right)} .
$$

Applying conditions (32), the ratios of deformations to stresses in a transversally-isotropic composite take the following form:

$$
\varepsilon_{r}=-\frac{v_{12}^{+}}{E_{1}^{+}} \sigma_{0}, \quad \varepsilon_{z}=\frac{1}{E_{1}^{+}} \sigma_{0} .
$$

Accordingly, the displacements are determined from the following formulae:

$$
\begin{aligned}
& u_{r}(r)=-\frac{v_{12}^{+}}{E_{1}^{+}} \sigma_{0} r, \\
& u_{z}(z)=\frac{1}{E_{1}^{+}} \sigma_{0} z,
\end{aligned}
$$

taking into consideration that in a given problem the conditions $u_{r}(0)=0$ and $u_{z}(0)=0$ must be met.

The conditions for the alignment of displacements in a problem on the joint deformation of the matrix and fiber in a cell of the composite at its longitudinal stretching and a problem about the longitudinal stretching of a homogeneous transversally-isotropic cell are the equality of axial displacements for the arbitrary $z=h$ and the radial displacements at the outer surface of the cell $r=b$ :

$$
\begin{aligned}
& u_{r}(b)=u_{r}^{*}(b), \\
& u_{z}(h)=u_{z}^{\circ}(h)=u_{z}^{*}(h) .
\end{aligned}
$$

The second ratio from (38), considering (11) and (37), takes the following form:

$$
\frac{\sigma_{0}}{E_{1}^{+}}=\frac{\sigma_{0}^{*}\left(1-v_{-}^{*}-2 v_{-}^{*} v_{+}^{*}\right)}{E_{+}^{*}\left(1-v_{-}^{*}\right)}-\frac{2 E_{-}^{*} v_{+}^{*} B_{1}}{E_{+}^{*}\left(1-v_{-}^{*}\right)}
$$

\section{Determining the effective elastic constants}

Considering (25) to (27) and (35), we obtain the ratio:

$$
\begin{aligned}
& \frac{1}{E_{1}^{+}}=\frac{1}{d_{+}^{\circ}+f\left(d_{+}^{*}-d_{+}^{\circ}\right)} \times \\
& \times\left(\begin{array}{l}
-\frac{2 E_{-}^{*} v_{+}^{*} f v_{-}^{\circ}}{E_{+}^{*}\left(d_{1}-d_{2}\right)} d_{+}^{*}+ \\
+\left(\begin{array}{l}
\frac{\left(1-v_{-}^{*}-2 v_{-}^{*} v_{+}^{*}\right)}{E_{-}^{*}\left(1-v_{-}^{*}\right)}+ \\
+\frac{2 v_{-}^{*}}{\left(1-v_{-}^{*}\right)} \frac{v_{+}^{*}}{E_{+}^{*}} \frac{f E_{-}^{\circ}\left(1-v_{-}^{*}\right)+d_{1}-d_{2}}{d_{1}-d_{2}}
\end{array}\right) d_{+}^{\circ}
\end{array}\right) .
\end{aligned}
$$

After the transformations, we obtain a formula for determining the longitudinal module of elasticity for a composite material with the transversally-isotropic matrix and fiber:

$$
E_{1}^{+}=\frac{E_{-}^{*} E_{+}^{*}\left(1-v_{-}^{*}\right)\left(d_{1}-d_{2}\right)\left(d_{+}^{\circ}+f\left(d_{+}^{*}-d_{+}^{\circ}\right)\right)}{2\left(E_{-}^{*}\right)^{2} v_{+}^{*} v_{-}^{\circ} f d_{+}^{*}\left(1-v_{-}^{*}\right)-d_{+}^{\circ} E_{+}^{*}\left(1-v_{-}^{*}-2 v_{-}^{*} v_{+}^{*}\right)\left(d_{1}-d_{2}\right)-k_{1}},
$$

where

$$
k_{1}=2 d_{+}^{\circ} E_{-}^{*} v_{+}^{*} v_{-}^{*}\left(f E_{-}^{\circ}\left(1-v_{-}^{*}\right)+d_{1}-d_{2}\right) .
$$

Then, considering the expression for $B_{1}$ in (27), we obtain a ratio for the Poisson coefficient $v_{12}$ :

$$
v_{12}^{+}=\frac{E_{+}^{*}\left(1-v_{-}^{*}\right)\left(2 f v_{-}^{\circ} E_{-}^{*} d_{+}^{*}-v_{-}^{*} d_{+}^{\circ}\left(d_{1}-d_{2}+2 f E_{-}^{\circ}\right)\right)}{2\left(E_{-}^{*}\right)^{2} v_{+}^{*} v_{-}^{\circ} f d_{+}^{*}\left(1-v_{-}^{*}\right)-d_{+}^{\circ} E_{+}^{*}\left(1-v_{-}^{*}-2 v_{-}^{*} v_{+}^{*}\right)\left(d_{1}-d_{2}\right)-k_{1}} .
$$

Similarly, under longitudinal compression, we determine:

$$
E_{1}^{-}=\frac{E_{-}^{*} E_{+}^{*}\left(1-v_{+}^{*}\right)\left(d_{3}-d_{4}\right)\left(d_{-}^{\circ}+f\left(d_{-}^{*}-d_{-}^{\circ}\right)\right)}{2\left(E_{-}^{*}\right)^{2} v_{-}^{*} v_{+}^{\circ} f d_{-}^{*}\left(1-v_{+}^{*}\right)-d_{-}^{\circ} E_{-}^{*}\left(1-v_{+}^{*}-2 v_{-}^{*} v_{+}^{*}\right)\left(d_{3}-d_{4}\right)-k_{2}}
$$

here

$$
\begin{gathered}
k_{2}=2 d_{-}^{\circ} E_{+}^{*} v_{-}^{*} v_{+}^{*}\left(f E_{+}^{o}\left(1-v_{+}^{*}\right)+d_{3}-d_{4}\right) \\
v_{12}^{-}=\frac{E_{-}^{*}\left(1-v_{+}^{*}\right)\left(2 f v_{+}^{o} E_{+}^{*} d_{-}^{*}-v_{+}^{*} d_{-}^{\circ}\left(d_{3}-d_{4}+2 f E_{+}^{o}\right)\right)}{2\left(E_{+}^{*}\right)^{2} v_{-}^{*} v_{+}^{\circ} f d_{-}^{*}\left(1-v_{+}^{*}\right)-d_{-}^{\circ} E_{-}^{*}\left(1-v_{+}^{*}-2 v_{-}^{*} v_{+}^{*}\right)\left(d_{3}-d_{4}\right)-k_{2}},( \\
d_{3}=E_{+}^{*}(f-1)\left(1-v_{+}^{o}\right), d_{4}=E_{+}^{o}\left(f\left(1-v_{+}^{*}\right)+\left(1+v_{+}^{*}\right)\right), \\
d_{-}^{\circ}=\frac{E_{-}^{*}(f-1)\left(1-v_{-}^{\circ}-2 v_{-}^{\circ} v_{+}^{\circ}\right)-E_{-}^{\circ}\left(f\left(1-v_{-}^{*}-2 v_{+}^{\circ} v_{-}^{*}\right)+\left(1+v_{-}^{*}\right)\right)}{E_{-}^{\circ}}
\end{gathered}
$$

$d_{-}^{*}=\frac{E_{-}^{*}(f-1)\left(1-v_{-}^{\circ}-2 v_{+}^{*} v_{-}^{\circ}\right)-E_{-}^{\circ}\left(f\left(1-v_{-}^{*}-2 v_{-}^{*} v_{+}^{*}\right)+\left(1+v_{-}^{*}\right)\right)}{E_{-}^{*}}$
To determine the mechanical properties of a transversally-isotropic composite, one needs to know the values of the 
five elastic constants: the modules of elasticity $E_{1}$ and $E_{2}$, the Poisson coefficients $v_{12}$ and $v_{23}$, as well as the shear module $G_{12}$. It is possible to determine this system of effective elastic constants based on the use of the conditions for aligning the relevant displacements for different types of the linear and shear deformation of the composite cell.

\section{An example of the homogenization of a multimodular composite and an analysis of the results obtained}

Based on the derived formulae (41), (42), we calculated values of the longitudinal elasticity module $E_{1}^{+}$and the Poisson coefficient $v_{12}^{+}$. A composite was studied, the constituent elements of which are the isotropic matrix and fiber of the following elastic characteristics:

$$
\begin{aligned}
& E_{+}^{\circ}=60.4 \mathrm{GPa}, v_{+}^{\circ}=0.38, \quad E_{-}^{\circ}=48.32 \mathrm{GPa}, v_{-}^{\circ}=0.342, \\
& E_{+}^{*}=5.55 \mathrm{GPa}, v_{+}^{\circ}=0.37, \quad E_{-}^{*}=4.44 \mathrm{GPa}, v_{-}^{*}=0.333 .
\end{aligned}
$$

Fig. 1 shows, by a continuous line, the dependence of the longitudinal elasticity module $E_{1}^{+}$on the volumetric fiber content in the range $f=0,1 \ldots 0,8$. The Poisson coefficients values $v_{12}^{+}$in this range remain almost constant, slightly varying from 0.418 to 0.426 .

Compute values for the longitudinal elasticity module $E_{1}^{-}$ and the Poisson coefficient $v_{12}^{-}$from formulae (43), (44) for a composite with the specified elastic characteristics at the volumetric fiber content $f \in[0.1 ; 0.8]$.

The dotted line in Fig. 1 shows the dependence of the longitudinal module of elasticity under compression $E_{1}^{-}$on the volumetric fiber content. The Poisson coefficient values $v_{12}^{-}$ in this interval of change $f$ range from 0.297 to 0.303 .

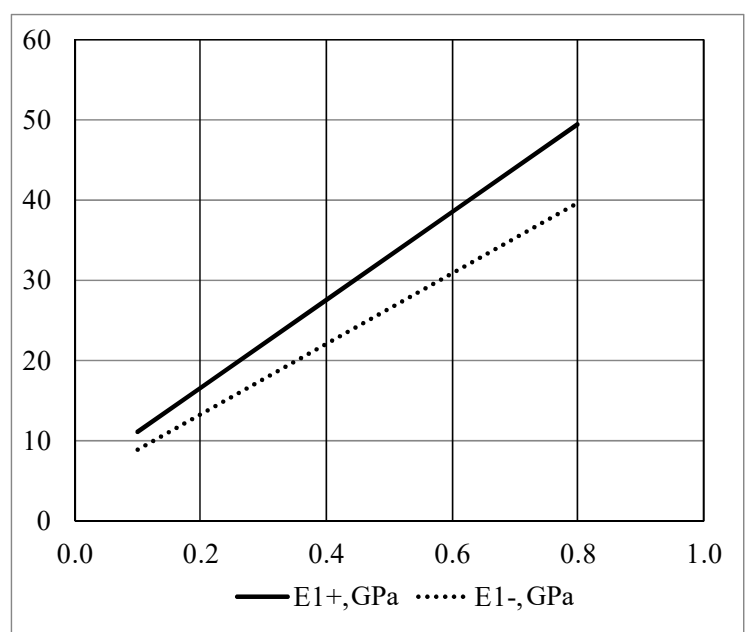

Fig. 1. Dependence of the longitudinal modulus of elasticity $E_{1}^{+}$and $E_{1}^{-}$on the volumetric fiber content $f$ in a composite

The results obtained indicate that in the cases of the composite cell stretching and compression, as the fiber's volumetric content increases, the effective longitudinal module of elasticity $E_{1}$ in a transversally-isotropic composite material grows according to the law close to the linear one. The effective Poisson coefficient $v_{12}$ in both cases is close to constant. In this case, the value of $E_{1}$ at the constant values of $f$ at stretching is, on average, larger by $25 \%$ than the corresponding values of this indicator at compression. The value of the effective Poisson coefficient $v_{12}$ at stretching exceeds its value at compression by $40 \%$ on average.

Note that for the case

$$
E_{-}^{*}=E_{+}^{*}, v_{-}^{*}=v_{+}^{*}, E_{-}^{\circ}=E_{+}^{\circ}, v_{-}^{\circ}=v_{+}^{\circ},
$$

we derive, from formulae (41) and (43), a formula for the instantaneous longitudinal module of elasticity $E_{1}$, obtained in [5].

\section{Discussion of results of devising a procedure for the homogenization of a transversally-isotropic composite}

The resulting formulae (41) to (44) for the effective values of the longitudinal module of elasticity and Poisson's coefficient for a fibrous transversally-isotropic composite, in contrast to existing formulae for effective constants, make it possible to take into consideration the presence of differences in the mechanical characteristics of a composite material at the longitudinal stretching and compression. Their use could improve the design process of structures, which include transversally-isotropic composite materials.

In this case, it is necessary to take into consideration the limitations of using the obtained analytical ratios related to the possibility of representing a composite in the form of a homogeneous material. The formulae for the effective characteristics of a homogenized composite adequately reflect its mechanical properties if the length of the fibers is sufficiently large compared to their diameter. The fiber reinforcement in a composite must also be dense. For most of the composites used in practice, these conditions are met.

This study is a continuation of our research into the issues related to the homogenization of fibrous transversallyisotropic composites in terms of determining effective mechanical constants for the multimodular composite materials. A formula for the transverse elasticity module $E_{2}$ at stretching and compression was obtained in [14]. In the future, we expect to continue studies in order to obtain a system of effective constants, which would fully describe the mechanical properties of a transversally-isotropic fibrous composite. This implies finding an effective second-kind elasticity module (the shear module) $G_{12}$, as well as the effective values of the Poisson coefficients $v_{21}$ and $v_{23}$ at the longitudinal stretching and compression. To solve this problem, the kinematic conditions for the alignment of displacements, used in the current paper, should be modified for the shear deformation of the composite cell. In addition, the promising areas for studying the homogenization of multimodular composites are those associated with the refinement of a composite model, for example, taking into consideration the non-linearity of its elastic properties, the presence of the plastic and viscoelastic properties of a composite.

\section{Conclusions}

1. We have proposed a procedure for the homogenization of a transversally-isotropic fibrous multimodular composite, based on using the kinematic conditions for the alignment of the axial and radial displacements of a composite and its components. It makes it possible to derive values of the effective mechanical composite characteristics taking into consideration their differences at stretching and compression. 
2. Two auxiliary problems were solved in order to solve a problem on the homogenization of a multimodular fibrous composite: determining the displacements of the matrix and fiber at their joint longitudinal stretching and compression and determining the displacements points of a homogeneous transversally-isotropic composite at its longitudinal deformation.

3. At the longitudinal stretching and compression, we have derived, for a transversally-isotropic multimodular composite, formulae (41) and (43), in order to determine the effective longitudinal module of elasticity of the first type, as well as formulae (42) and (44) for finding the effective Poisson coefficient in the plane of isotropy. The obtained for- mulae for the effective constants determine the dependences of these quantities in the share of fibers in a composite's material and the mechanical characteristics of its components, taking into consideration their differences at stretching and compression.

4. Formulae for the effective mechanical constants have been applied for homogenizing a particular multimodular composite. Our study of the multimodular fibrous composite shows that the effective longitudinal elasticity module for different values of the volumetric content of fibers at stretching exceeds that at compression by $25 \%$ on average. The Poisson's coefficient $v_{12}$ at stretching is, on average, approximately $40 \%$ larger than that at compression.

\section{References}

1. Klasztorny, M., Konderla, P., Piekarski, R. (2009). An exact stiffness theory for unidirectional xFRP composites. Mechanics of Composite Materials, 45 (1), 77-104. doi: https://doi.org/10.1007/s11029-009-9064-y

2. Cruz-González, O. L., Rodríguez-Ramos, R., Otero, J. A., Bravo-Castillero, J., Guinovart-Díaz, R., Martínez-Rosado, R. et. al. (2018). Viscoelastic effective properties for composites with rectangular cross-section fibers using the asymptotic homogenization method. Generalized Models and Non-Classical Approaches in Complex Materials 1, 203-222. doi: https://doi.org/10.1007/978-3-31972440-9_10

3. Daridon, L., Licht, C., Orankitjaroen, S., Pagano, S. (2016). Periodic homogenization for Kelvin-Voigt viscoelastic media with a Kelvin-Voigt viscoelastic interphase. European Journal of Mechanics - A/Solids, 58, 163-171. doi: https://doi.org/10.1016/ j.euromechsol.2015.12.007

4. Pathan, M. V., Tagarielli, V. L., Patsias, S. (2017). Numerical predictions of the anisotropic viscoelastic response of uni-directional fibre composites. Composites Part A: Applied Science and Manufacturing, 93, 18-32. doi: https://doi.org/10.1016/j.compositesa.2016.10.029

5. Grebenyuk, S., Klymenko, M., Titova, O., Boguslavska, A. (2015). Effective longitudinal elastic modulus of the composite with viscoelastic matrix and transtropic fiber. 20th International Scientific Conference Mechanika. Kaunas: Kaunas University of Tehnology, 96-100.

6. Wang, Y., Huang, Z. (2017). A Review of Analytical Micromechanics Models on Composite Elastoplastic Behaviour. Procedia Engineering, 173, 1283-1290. doi: https://doi.org/10.1016/j.proeng.2016.12.159

7. Zhang, L., Yu, W. (2015). Variational asymptotic homogenization of elastoplastic composites. Composite Structures, 133, 947-958. doi: https://doi.org/10.1016/j.compstruct.2015.07.117

8. Ambartsumyan, S. A. (1982). Raznomodul'naya teoriya uprugosti. Moscow: Nauka, 320.

9. TSvelodu, I. Yu. (2008). O raznomodul'noy teorii uprugosti. Prikladnaya matematika i teoreticheskaya fizika, 49 (1), $157-164$.

10. Yershova, A. U., Martirosov, M. I. (2015). Experimental study heterogeneous polymer composites with finely divided filler. Stroitel'naya mehanika inzhenernyh konstruktsiy i sooruzheniy, 5, 68-72.

11. Bessonov, D. E., Zezin, Yu. P., Lomakin, E. V. (2009). Multimodulus Behevior of the Grained Composites on the Base of Unsaturated Polyetheres. Izvestiya Saratovskogo universiteta. Novaya seriya. Seriya Matematika. Mehanika. Informatika, 9 (4), 9-13.

12. Pakhomov, B. M. (2017). Alternative model of isotropic material with different modulus. Herald of the Bauman Moscow State Technical University. Series Mechanical Engineering, 6, 35-45. doi: https://doi.org/10.18698/0236-3941-2017-6-35-48

13. Nassef, A. S. E., Dahim, M. A. (2016). New Bi-modular Material Approach to Buckling Problem of Reinforced Concrete Columns. Mechanical Engineering Research, 6 (1), 19-28. doi: https://doi.org/10.5539/mer.v6n1p19

14. Grebenyuk, S., Klymenko, M., Smoliankova, T., Koval, R. (2019). Effective Characteristics of the Multi-Modular Composites under Transverse Stretching. Materials Science Forum, 968, 511-518. doi: https://doi.org/10.4028/www.scientific.net/msf.968.511 